\title{
Justiças e ajustes sociais
}

\author{
Ana Cláudia D. R. Marques ${ }^{1}$
}

Em diversas narrativas versando sobre o tema geral das vinganças privadas, emerge, em algum momento, como problema geral, a concepção de justiça na qual se apóiam suas proposições, ou a seqüência dos atos segundo são descritos. Deriva daí, como questão mais específica, o conflito entre preceitos de Justiça oficial e outras concepções de justiça nativas que costumam permear estes casos. Aparentemente, a fórmula consagrada de equacionamento entre as duas formas traduz a relação em incompatibilidade mais estrita. A Justiça pune a iniciativa privada de compensar um dano anteriormente sofrido, reforçando o princípio do monopólio estatal do uso da violência. E a iniciativa privada se sustenta no pressuposto ou verificação da ineficiência da Justiça para a compensação almejada. Pitt-Rivers (1977) sugere que, na verdade, a reparação do dano moral sofrido por um "homem de honra" não pode ser obtida, por princípio, através do mediador oficial, porque uma honra só pode ser reparada por quem tenha sido atingido pela ofensa que a maculou. Seja como for, prevalece a idéia de insuficiência da Justiça para lidar com determinado tipo de agravo. Eis aí uma questão complexa. Esta insuficiência pode ser problematizada de muitas formas, como por exemplo, em torno do funcionamento (muito criticado) das engrenagens oficiais, ou dos valores culturais que supostamente sustentam as ações privadas, ou da relação da Justiça com estes va-

\footnotetext{
${ }^{1}$ Doutora em Antropologia Social pelo Museu Nacional; publicou “Algumas faces de outros eus: honra e patronagem na Antropologia do Mediterrâneo" (Mana - Estudos de Antropologia Social, v.5, n. 1, 1998) e, com Jorge M. Villela, organizou Andarilhos e cangaceiros: a arte de produzir território em movimento (Univali, 1999). Contatos com a autora: aclaudia@bridge.com.br. B Agradeço a Marina Penido Burnier por sua atenta revisão dos aspectos jurídicos de que trato e por suas pertinentes sugestões. Ela está isenta, contudo, da responsabilidade pelas formulações contidas aqui, que cabem a mim.
} 
lores locais, ou do controle nem sempre devido e nem sempre desejável da máquina jurídica por determinadas forças sociais e por aí afora.

Todos estes assuntos merecem uma investigação cuidadosa e de dimensão mais alargada, mas eles se cruzam com uma questão bastante pontual que quero abordar aqui, que permite uma exploração preliminar destes problemas. Trata-se da condição dos integrantes do júri popular como os atores que fazem, provavelmente do modo mais privilegiado e agudamente sentido, a ponte entre as duas formas de justiça, bem como dos ajustes sociais que supõem. Minha intenção não é exatamente focalizar a instituição do Tribunal do Júri, embora isto possa vir à tona em alguns momentos, mas antes, através de elementos etnográficos, ressaltar a interpenetração das diferentes concepções de justiça que, mesmo antagônicas, compõem-se de modo peculiar no tratamento que uma determinada sociedade concede a certos atos. Atos que se podem definir em termos de violência, considerando que o Tribunal do Júri, na Justiça brasileira, tem como âmbito exclusivo de atuação os julgamentos dos 'crimes dolosos' contra a vida, ${ }^{2}$ quer resultem ou não na morte da vítima. Assim, uma etnografia destas atuações, em determinado local e tempo, deve fornecer indicações sobre o lugar concedido à violência em uma dada sociedade.

Em uma pequena comarca do interior de Pernambuco, a que chamarei aqui Monte Verde, ${ }^{3}$ costuma haver duas sessões anuais do Tribunal do Júri. Durante um dos períodos de trabalho de campo em que permaneci em Monte Verde, acompanhei uma dessas sessões, transcorrida entre outubro e novembro de 1999, ao longo da qual aconteceram sete julgamentos. Acompanhei a maior parte deles no plenário, mas estive presente também, em duas ocasiões, durante a votação secreta, contando, para isto, com a permissão do juiz e o acordo das partes. Embora uma parte significativa do material sobre o qual me apóio tenha origem naquela sessão,

${ }^{2}$ A competência do Tribunal do Júri está prevista no artigo 74 do Código de Processo Penal. Dizem respeito ao parágrafo primeiro e parágrafo segundo do artigo 121, artigo 122 parágrafo único e artigos 123, 124, 125, 126 e 127 do Código Penal.

${ }^{3}$ Adotei pseudônimo para as cidades e evitei utilizar nomes próprios para as pessoas. O respeito pelas suas privacidades é uma retribuição mínima pelo voto de confiança que depositaram tão francamente em mim, como pesquisadora, na abordagem de assuntos tão comprometedores em vários sentidos. Com o mesmo intuito, na medida em que o dado não tinha significado analítico, também omiti o sexo de alguns de meus interlocutores, usando o masculino como desinência comum. Em comunidades numericamente reduzidas como aquela em que realizei minha pesquisa de campo, certos detalhes são tão reveladores quanto nomes e, de fato, dificilmente se evita por completo as identificações. Procurei salvaguardá-las ao máximo, no limite da suficiência dos dados. 
conto também com registros de conversas, algumas mais formalmente estabelecidas, sob a forma de entrevistas, outras mais informais; uma parte delas ocorrida durante o período dos julgamentos, outras posteriores, nas quais tomaram parte intervenientes nos julgamentos, indivíduos interessados neles em virtude de sua ligação com o réu ou com a vítima e outros ainda que meramente comentavam os fatos, sem maior envolvimento com aqueles processos. $\mathrm{O}$ fato de contar com este material heterogêneo importa muito para a compreensão da interpenetração do que designei como concepções oficiais e nativas de justiça.

Com efeito, é muitas vezes difícil fazer a distinção entre as duas concepções de justiça, que ora parecem idênticas, ora mostram-se incompatíveis. De todo modo, uma alimenta a outra e as decisões concernentes a uma de costume têm a outra em consideração. Convém, por exemplo, não situar o fazer cumprir a lei acima da avaliação das conseqüências destes atos. Neste sentido, considerando definições propostas por Eckhoff (1973), o juiz, cuja função se situaria mais no nível das normas, pode encarnar também a figura do mediador, ocupado com a conciliação de interesses e com o futuro da relação entre as partes em litígio. Interferir em demasia no desencadeamento dos atos relativos a uma vingança, por exemplo Bou, conforme observou Herzfeld (1985: 26) em relação à punição oficial da prática tradicional do roubo de gado ou de tentativa de homicídio em uma aldeia montanhesa de CretaB, pode acarretar no agravamento de um conflito. Do ponto de vista oposto, é preciso coordenar as ações de acordo com o funcionamento da máquina jurídica, fazendo, inclusive, uso dela tanto quanto possível, para obter o resultado mais próximo do almejado. Prestar ou não depoimentos, declarar ou omitir conhecimento, recorrer ou não à justiça, ${ }^{4}$ são decisões tão estratégicas quanto fugir ou vingar um dano sofrido e que são tomadas levando em conta as circunstâncias vividas. Quem quer que se veja envolvido, de qualquer forma, com a administração de Justiça em relação a um ato criminoso tem como tarefa algo muito mais complexo do que avaliar se o acusado agiu ou não de acordo com os preceitos da lei, punindo-o na proporção do dano causado. É sobretudo necessário ter em mente o que vai resultar de cada passo do processo até ser dada a sentença. Neste sentido, os diferentes intervenientes parecem tomar a seu cargo o dever dos ajustes sociais, visando à paz social, ou aos seus interesses, ou às duas coisas ao mesmo tempo.

${ }^{4}$ Cabe ao representante do Ministério Público instaurar processo na maioria dos casos da esfera penal. De todo modo, certos casos de homicídio são precedidos de uma relação de conflito, envolvendo réu e vítima e, possivelmente, outros. O recurso à Justiça, neste momento, pode ser um elemento adicional na relação de hostilidade. 
Na vizinha comarca de Monsanto, um antigo tabelião confidenciou que um dia ele retardou a expedição de 17 mandados de prisão, a fim de avisar os interessado do que estava para acontecer. Em resultado, eles retiraram-se em peso da cidade, para onde não mais voltaram, suspendendo assim, já por vários anos, uma "questão de família", 5 que já eliminara mais de uma dezena de pessoas. Os mandados de prisão teriam como efeito apenas o acirramento dos ânimos, levando possivelmente a mais mortes, considerou ele. Este raciocínio não é de nenhum modo excepcional e tampouco estranho ao conhecimento de juízes, promotores, advogados e mesmo membros do Tribunal do Júri. Em certo sentido, as partes em litígio parecem por vezes se valer deste conhecimento partilhado para justificar suas omissões. Não declarar o nome do agressor, mesmo quando instado pela Justiça, é uma forma de proteger-se de futuras vinganças e de não chamar sobre si a atenção da máquina judicial, caso as posições de vítima e agressor venham a ser trocadas. A instauração de um processo judicial não encerra uma relação de hostilidade; muitas vezes toma-se um instrumento de mediação na relação entre as partes e conscientemente utilizado por elas, com finalidades específicas que se situam além dos interesses da Justiça e das boas intenções de seus atores. De qualquer forma, o que fica muitas vezes expresso é o convencimento de que a possibilidade de punição pela Justiça, o que lido de outra maneira corresponde à delegação para outras instâncias da compensação pelo dano sofrido, pode não dissolver o antagonismo entre as partes, mas acrescentar-se a ele como novo fator.

Nos julgamentos a que compareci, seja como for, uma possível dimensão de mediação e de conciliação, se não esteve ausente, era muito pouco perceptível. O momento do julgamento tendeu, algumas vezes, a coroar um processo bastante longo, que não raro perdurou por vários anos. Nestas ocasiões, o julgamento ganha um caráter residual, desfecho definitivo de um processo devidamente arrumado em outros âmbitos. Assim, a incumbência dos jurados assemelhou-se a um referendo dos arranjos efetuados fora do sistema judiciário. Como, por exemplo, no caso de uma vingança, em que as duas famílias envolvidas construíram, ao longo de cerca de 10 anos, um meio de convívio possível, através do que poderíamos chamar método de evitação mútua; da esposa acusada de conivência na morte do marido, que voltou a casar e levar uma vida regular; do homem, pai de família respeitado e vizinho estimado, que se supôs vingar uma agressão a seu irmão; do deficiente mental que, de retorno da penitenciária, voltou a uma vida calma, como

${ }^{5}$ Utilizei aspas duplas exclusivamente nas designações de termos nativos. Por este motivo as aspas simples foram reservadas para alusão a termos ou expressões jurídicos ou presentes na literatura citada. 
de costume, respeitosamente distante da família do homem que matou e das bebidas que exaltavam seus ânimos. Em todos estes casos, os ajustes sociais pareceram, em boa medida, ter prevalecido e até subordinado a atuação da Justiça. Embora não se deva excluir a possibilidade dos trâmites judiciários, dos quais o julgamento é apenas o ponto culminante, constituírem parte significativa nos processos dos ajustes sociais.

\section{Justiça e justiça}

Nos julgamentos como um todo, pareceu muito ambígua a noção da aplicação da Justiça. Acusação e defesa procuram convencer os jurados de que suas teses correspondem à solução mais justa para cada caso discutido. Evidentemente, ambas têm seus objetivos e métodos amparados pelo Direito, pois não é preciso pensar que se trata simplesmente de driblar as engrenagens da máquina da Justiça. ${ }^{6}$ Mas cada caso, e mais especialmente seu registro nos autos, é suficientemente ambíguo para que se possa discutir seu enquadramento mais adequado, tendo em vista não apenas aquele conteúdo, como também as sanções legais que se lhe pode aplicar. Cabe então às duas partes em disputa nos julgamentos convencer os jurados acerca da sua proposta de enquadramento do delito discutido, e para isto fazem largamente apelo a seu senso de justiça, ainda que, assim procedendo, certas regras fundamentais de um código jurídico possam ser atingidas. Neste sentido, a legítima defesa pode corresponder não apenas aos casos de reação a uma agressão iminente, real ou putativa, como também àqueles em que se pode considerar aceitável o cometimento de um homicídio, ou em que se julgue excessiva a punição cabível para o ato cometido. Durante os julgamentos pelo Tribunal do Júri, nos discursos de acusação e defesa, tive a freqüente sensação de assistir deslizamentos semânticos abrangidos nas noções de Justiça como aplicação, em larga medida técnica, das regras previstas nos códigos legais, e de justiça como valor ético moral. Sentidos que se distinguem, mas que também, certamente, alimentam-se mutuamente.

Mais do que um delito, são muitas relações que estão envolvidas no tribunal. Relações nas quais se envolvem vítimas e réus, suas respectivas famílias e, no caso mais concreto de pequenas comarcas, como aquelas em que desenvolvi minha pesquisa, de todos aqueles que participam de seu julgamento direta ou indireta-

${ }^{6} \mathrm{O}$ recurso a métodos reprováveis do ponto de vista legal ou ético, sobejamente conhecidos e aplicados por todo lado, pode ser ou não empregado no contexto social que está sendo contemplado, tanto quanto em qualquer outro lugar. O que está em jogo, no entanto, é a forma como as duas partes formulam suas representações dos fatos de modo a serem, estas representações e não os fatos, tratadas (representadas) em tribunal (cf. Geertz 1983:173-175). 
mente. Este envolvimento torna a tarefa do Tribunal do Júri especialmente delicada. E, contudo, este envolvimento é também um elemento essencial da captura local de uma maquinaria aparentemente exótica, de origem estrangeira, mas contando com peças ${ }^{7}$ e arranjos nativos. Com efeito, a complexidade da máquina jurídica, que inicialmente parece exigir o comando apenas de iniciados, sofre acoplamentos de engenhos estranhos, modificando e ajustando seu funcionamento. É desta forma que entendo a prática já institucionalizada das conversas precedendo um julgamento pelo Tribunal do Júri. A partir de regras (artigos 434, 435, 436 e 439) do Código de Processo Penal, é designado um certo número Buma centena, no caso da comarca de Monte VerdeB de cidadãos de bons antecedentes, dos quais 21 serão sorteados para compor o Tribunal do Júri. No dia do julgamento, o conselho de sentença será composto por apenas 7 destes membros, também sorteados, a cada sessão de julgamento. ${ }^{8}$ Durante o sorteio, os representantes do Ministério Público e da defesa podem, cada um dos lados, recusar até três nomes sorteados. ${ }^{9}$ Excluem-se deste cômputo todas as restrições legalmente formuladas em relação à participação no conselho de sentença, que dizem respeito à natureza da relação reconhecida entre o membro do corpo de jurados sorteado e o réu, a vítima, o juiz, o advogado, o promotor ou outro membro do conselho de sentença anteriormente sorteado, definida em termos de grau de parentesco e afinidade. ${ }^{10}$ Este direito, conforme testemunhei, é plenamente exercido, de modo que as rejeições chegam a ser esgotadas por uma ou ambas as partes. As razões para a recusa não são publicamente explicitadas. Mas reconhece-se, tacitamente, que elas dizem respeito a antecipações deduzidas com relação ao voto do jurado sorteado. Antecipação que se alimenta do conhecimento que as partes possuem de sua posição na rede social e, certamente também, da opinião acerca da conversa travada com ele, às vésperas do julgamento, versando especificamente sobre o julgamento.

${ }^{7}$ Juízes e promotores, em regra, não são naturais da comarca em que trabalham, somente estabelecem residência na região, em geral mais prolongada no caso dos primeiros, mas nem tanto no caso dos outros. Não será por acaso que o promotor contava, nas audiências, com a ajuda de um promotor ad hoc, um antigo e conhecido rábula da cidade de Monte Verde, que depois de muitos anos veio a obter seu diploma de Direito. Os advogados são muitas vezes naturais ou radicados na região, embora o recurso a advogados de fora, da capital, principalmente, seja um aspecto tático nada desprezível, de que se faz uso nos julgamentos. Todos os demais serventuários da Justiça costumam ser nascidos ou radicados na cidade.

${ }^{8}$ Os artigos 427, 428 e 433, 442, 445, 447, 457 do Código de Processo Penal são os que, principalmente, regulam estes sorteios e suas condições.

${ }^{9}$ Artigo 459, parágrafo segundo do Código de Processo Penal.

${ }^{10}$ Artigos 255, 458, 462 e arguição 106 do Código de Processo Penal. 
Segundo um membro do corpo de jurados, várias vezes sorteado naquela sessão, ele foi procurado por ambas as partes interessadas em todos os julgamentos, sem exceção. Procura-se, nestas ocasiões, convencer o possível jurado das compreensíveis razões para o cometimento do crime Bé comum fazer apelo à má reputação ou maus aspectos da personalidade da vítimaB ou da barbaridade do ato do acusado, o que dá indícios de um sistema de justiça comparável à Justiça oficial. ${ }^{11}$ Agindo assim, aqueles que são próximos do réu ou da vítima apenas adotam o comportamento que se espera deles. A conversa com os jurados é uma convenção. É um dos assuntos recorrentes nos debates informais sobre os julgamentos e um dos aspectos alegadamente incômodos da posição de membro do corpo de jurados, conforme declararam também outros participantes daquela e de outras sessões. Testemunhei, inclusive, a esposa do juiz, em um intervalo de julgamento, aconselhar os membros do conselho de sentença a decidirem apenas segundo suas consciências, na mesma senda das recomendações que tantas vezes vi fazerem à população mais carente, nas eleições políticas: fazer com que o interlocutor acredite na adesão à sua causa, mas votar segundo sua apreensão do caso. O problema imediato com que se defrontam os jurados, no entanto, também é similar ao dos eleitores, e mais agravado. Não obstante o voto ser secreto em ambos os casos, não é difícil avaliar como é que cada um votou. Mera dedução lógica no caso da unanimidade dos $7 \times 0$, mas plenamente reconhecível, muitas vezes, até nos $4 \times 3$. No único caso de uma ré $\mathbf{B e m}$ todos os demais os acusados eram homensB, acusada de ter contribuído com o amante no homicídio de seu marido, a composição do conselho de sentença, de quatro mulheres e três homens, inspirou, ao início daquele julgamento, uma piada sobre seu resultado. A absolvição por 4x3 efetivamente se cumpriu. Coincidência? Daquele júri tive oportunidade de conversar com três membros do conselho de sentença, dois homens e uma mulher. Admitiu-se ou, em um dos casos, ficou evidente que decidiram de acordo com o que foi antecipado. Além disso, um dos homens confidenciou que acreditava que cada um dos seus colegas votou de acordo com seu sexo. Ouvi-o declarar, com convicção comparável, sua avaliação a respeito de um outro julgamento, cujo resultado foi uma condenação por $6 x 1$. A exceção daquele caso foi explicada por uma relação de vizinhança que ligava um jurado à família do réu. A distribuição dos votos é bastante

${ }^{11} \mathrm{~A}$ partir das informações que recolhi, há convenções com relação a modos, bem como a argumentos, relacionadas à prática dos "pedidos" aos membros do corpo de jurados. Neste domínio, então, efetuar-se-ia uma operação muito similar àquela desempenhada no sistema judiciário, de submissão da variedade dos casos ao conjunto limitado de normas (ou da representação dos fatos à representação das representações). Os limites desta comparação, porém, só podem ser definidos com uma pesquisa mais dirigida a tal objetivo. 
notável, tendo em conta ainda que a cumplicidade da ré, se efetiva, não teve nenhuma testemunha. Apesar de a defesa ter insistido que não se tratava de um julgamento sobre adultério, mas de homicídio, é bastante plausível que as duas coisas estivessem, na verdade, em discussão. Como se vê, o que ocorre em uma pequena comarca como Monte Verde é um comprometimento dos jurados em relação às partes, fator que não se exclui, segundo entendo, mas toma parte fundamental nas formulações nativas de justiça, em aguda contradição, neste sentido, às exigências de neutralidade supostas na Justiça oficial.

\section{"Pedidos"}

As conversas com os jurados prestam-se como auxílio para estabelecer um mapa das simpatias e antipatias em relação aos implicados em determinado julgamento, sobretudo quando as predisposições dos membros do corpo de jurados não são tão diretamente antecipáveis. E, claro, tenciona-se também captar o máximo de votos possível para a causa em debate. Com este objetivo são mobilizados aqueles que irão conversar pessoalmente com os 21 jurados, sendo o resultado da conversa uma informação importante para defesa e acusação ${ }^{12}$ na definição das aceitações e recusas durante o sorteio do conselho de sentença. Estipula-se cuidadosamente quem irá procurar cada um dos 21 possíveis jurados, sendo em geral designada mais de uma pessoa, para dar conta de todos eles, às vésperas do julgamento. Os escolhidos devem, tanto quanto possível, ter uma posição social estratégica, ser um centro privilegiado de relações sociais, conforme observei acerca de algumas pessoas que já desempenharam este papel. É com este intuito que destacam os mais proeminentes membros da família ou, em certos casos, alguém de posição superior, com quem se mantém laços mais fortes de amizade ou patronagem. Fica estabelecido também, conforme os laços pessoais e a antecipação da forma como os jurados votarão, a divisão de tarefas entre os protagonistas das conversas.

Pois o valor de cada uma delas pode variar. Embora genericamente designados "pedidos", conforme a pessoa que o profere, pode tratar-se quase de uma ordem. Como negar um pedido a alguém, de posição superior, que porventura já prestou um favor ou com quem se deseja estar em bons termos, para qualquer necessidade imprevista, ou ainda cuja superioridade em si, mal racionalizada quanto a sua pos-

${ }^{12}$ Informaram de que o representante do Ministério Público não se envolve nesta prática das conversas com jurados. Contudo, conforme referi, os jurados ouvem pedidos tanto da parte do réu quanto da vítima. Não me foi relatado, tampouco, a participação pessoal e direta de advogados de defesa nestas visitas. Assim, depreendo que os advogados talvez discutam mais abertamente este aspecto do julgamento com o réu e aqueles que o apóiam, enquanto os promotores tendem a manterse aparte deste processo, sem necessariamente, contudo, deixar de valer-se dos seus resultados. 
sível utilidade futura, intimida? O caso mais crítico de que possuo informação a este respeito não foi a julgamento naquela sessão do júri de que participei. Contudo, tive o privilégio de ter acompanhado diferentes etapas daquele processo, cuja rapidez é já indicativa das forças que o dominaram. Um homem foi morto por pancadas na cabeça, dias antes de minha chegada a Monte Verde. O nome do suspeito, devidamente detido, circulava como uma certeza nos cochichos da cidade, com tamanha intensidade que não tardaram a chegar em ouvidos forasteiros. Tratava-se do irmão de um empregado de confiança de um magistrado residente, mas não atuante, na comarca. Muito embora o acusado tivesse uma conduta reprovada pelo irmão, seu patrão e familiares deste, ele não deixou de encontrar lugar, voluntária ou involuntariamente, sob a aura da proteção do magistrado. Ainda que em nenhum momento, até a aproximação do julgamento, tenham sido lançadas dúvidas sobre a autoria do homicídio. Não testemunhei o envolvimento pessoal e direto do magistrado durante as etapas que antecederam o julgamento daquele caso, sobre o qual, acrescento, ele jamais conversou comigo com suficiente profundidade. Soube, no entanto, de sua presença inesperada, passageira e significativa no julgamento, diante dos olhos dos jurados, ocorrido menos de um ano após o crime de que foi absolvido pelo conselho de sentença. Certamente, a desenvoltura com que um magistrado penetra em uma corte de julgamento não é surpreendente nem suspeita em si mesma. Contudo, a sua ligação com o réu foi objeto, conforme também fui informada, da conversa sussurrada pelo corpo de jurados, antes do sorteio do conselho de sentença. Alguns daqueles 21 componentes terão declarado ter sido pessoalmente visitados por ele. Assim o passeio pela corte ganhou o seu significado. Aquele julgamento foi o único em que o jurado com quem conversei declarou ter certeza antecipada de seu voto.

Com efeito, os "pedidos" aos jurados são prática tão institucionalizada que, parece-me, chega a compelir os interessados a tomarem parte nela, ainda que destituídos dos meios favoráveis para exercê-la. Alguns dos júris a que assisti envolviam famílias bastante humildes, aparentemente sem o gozo de amizades importantes e de membros com posição mais saliente na sociedade. ${ }^{13}$ Assim mesmo, na qualidade de quase desconhecidos, mobilizaram-se nos "pedidos". De certa forma, a conversa com os jurados pode parecer quase indiferente, com cada uma das partes cumprindo seu papel, sobretudo quando o peso social de ambas Bo que

\footnotetext{
${ }^{13}$ Em uma pequena comarca como a de Monte Verde, a relevância da classe social no desenrolar dos processos e dos julgamentos -fator isolado por Kant de Lima (1996) no acionamento de princípios distintos no sistema criminal- sem deixar de ser efetiva, é freqüentemente contrabalançada pelas relações pessoais estabelecidas entre indivíduos pertencentes a diferentes estratos sociais. A exemplo de outras circunstâncias, elas são acionadas também na relação com o sistema judiciário, conforme os exemplos
} já fornecidos ilustram sobejamente. 
sempre inclui as redes de relações em que estão inseridasB é aproximado. Mas se uma das partes não cumpre seu papel, resulta que sua omissão poderá ser interpretada como desinteresse, senão endosso da tese contrária.

Quando um ex-prefeito foi assassinado pelo mais célebre valentão de Monte Verde, anos atrás, a família da vítima apartou-se de toda interferência no andamento do processo. Sua atitude, além de não deixar de favorecer a defesa, justificou também Bcomo argumentação discursiva, no mínimo, em torno da sua condutaB a omissão da única testemunha ocular do fato, profundamente pressionada pela sua involuntária condição de antagonismo com alguém tão notoriamente perigoso. Menos de cinco anos depois, porém, o valentão tomou-se vítima. A autoria de seu assassinato, outra vez, era sobejamente conhecida, tendo sido também visualmente testemunhada. Tratava-se de uma pessoa, a exemplo da vítima, já ingressa na carreira de armas, havendo mesmo quem garanta ter sido contratada para executar aquele serviço. $\mathrm{O}$ julgamento deste segundo homicídio aconteceu, tendo como resultado, segundo me disseram, uma absolvição por 7x0. A viúva da vítima deste processo explicou-me que se ausentou deliberadamente da cidade, com suas filhas, no dia do julgamento. Ela também informou-me que não procurou os jurados para pedir pela sua causa, embora se trate de uma pessoa muito "considerada" em Monte Verde. Em razão de sua omissão, terá recebido muitos telefonemas de membros do corpo de jurados, que lhe perguntavam como deveriam votar. Ela terá decidido deixá-los livres para julgar como quisessem. Liberados deste compromisso, aderiram à causa contrária, possivelmente ciosos de manterem em bons termos a relação, mesmo que quase inexistente, com o réu daquele julgamento, de "fama" bastante conhecida e pertencente a uma das famílias dominantes do sertão do Pajeú.

\section{O julgamento e o juízo em deliberação}

Em mais de uma ocasião ouvi críticas agudas à instituição do Tribunal do Júri, partidas de profissionais do Direito, bem como da própria população, e em particular de quem já foi membro do conselho de sentença. Independentemente de onde se origina, a reprovação baseia-se quase sempre no fato de não haver isenção possível no julgamento de qualquer um que esteja pessoalmente ligado a uma das partes em litígio, o que acontece com incômoda freqüência em uma cidade pequena como Monte Verde. Mesmo quando não há uma ligação direta com alguma das partes, costuma haver referências comuns, relações partilhadas ou simplesmente uma pertença a um mesmo universo social. $\mathrm{O}$ juiz de uma pequena comarca próxi- 
ma, residente em Monteverde, proclama que deveriam também caber ao magistrado as decisões relativas aos crimes que hoje são julgados pelo Tribunal do Júri, dado o seu treinamento para tratar juridicamente de toda sorte de delitos e pelo maior grau de neutralidade que seu cargo lhe faculta junto à população. Por outro lado, vários cidadãos que integraram o Tribunal do Júri expressam desagrado pela delicadeza de sua posição perante os réus e as vítimas e suas famílias. Conforme salientam, muitas vezes são pessoas com quem convivem desde a infância, cujas famílias são conhecidas ou próximas, sendo que isto pode ser verdadeiro para ambos os lados da disputa. Assim, os vários protagonistas dos julgamentos a que assisti tinham sua posição social nas redes de relações locais suficientemente conhecidas ou depreendidas por quem estava julgando, em virtude de relações pessoais diretas com eles ou através da partilha de um universo social comum. Não parecia ser casual, inclusive, que, ao longo dos discursos da acusação e da defesa, fossem feitas várias referências a locais e pessoas da cidade, mencionadas pelos nomes e até por apelidos, como se se tratasse de um patrimônio social comum. Ao longo da série de julgamentos, fui percebendo como este conhecimento se fazia um dado fundamental na resolução dos jurados, potencialmente acionado pelos profissionais do Direito em proveito de suas teses.

E no entanto, os resultados das sessões do Tribunal do Júri não são de todo antecipáveis. Durante os julgamentos, decisões importantes são tomadas, baseadas genuinamente nas alegações de acusação e defesa. Quando destaco elementos importantes nestas decisões, faço-o orientada pelo curso dos acontecimentos observados durante os julgamentos e por vezes apoiada em argumentos dos próprios jurados, confiados a mim. Na verdade, possivelmente muito em virtude de minha condição de forasteira, na época daquela sessão do Tribunal do Júri ainda recémchegada, surpreendi-me sinceramente com certas decisões e em alguns dos casos, chegada a hora da votação, eu não me sentia capaz de antecipar o resultado. Há indiscutivelmente julgamentos cuja realização parece simplesmente sancionar uma decisão prévia que não cabe bem ao juiz ou a quem quer que seja, mas a uma certa disposição social. Consoante as amizades do réu e os recursos Be não só os materiaisB de que dispõe, a tarefa da defesa torna-se muito simples.

Em dois dos julgamentos a que assisti, as famílias dos acusados ocupavam posições estratégicas. Pelas ruas, adivinhava-se a absolvição, em opinião virtualmente unânime. Ambos os réus tinham parentes muito próximos que eram serventuários da Justiça. No primeiro destes casos, o réu pertencia a uma família bem conceituada do município. Meses mais tarde, seu advogado, que viveu naquele julgamento sua estréia profissional em Tribunal do Júri, confidenciou-me que 
aceitou a causa sabendo da pouca exigência em tomo de sua atuação, por tratar-se de um julgamento em que a absolvição seria o resultado evidente. Tendo conhecido em bastantes detalhes o caso no qual tomou parte aquele réu, vim a entender aquele julgamento como o endosso do ponto de acomodação atingido fora das disputas judiciárias. Tratava-se de um homicídio cometido contra o irmão do assassino do pai do réu. O representante do Ministério Público pediu a condenação do acusado, em nome da recusa da vindita privada, motor do crime em julgamento, segundo sua interpretação. A absolvição do réu, no entanto, fez prevalecer a tese, não menos discutivelmente confirmada pelas provas dos autos, de uma legítima defesa putativa: um ou mais disparos efetuados pelo acusado justificaram-se pela sua alegada suposição de estar correndo risco de ser atingido por uma facada ameaçada pela vítima. Na verdade, já se haviam passado dez anos desde que os dois homicídios aconteceram, durante os quais as famílias dos assassinos e das vítimas foram encontrando meios de convívio social. Toda interferência em uma relação construída sobre apoios tão frágeis corre o risco de perturbá-la, como um sopro sobre um castelo de cartas. Independentemente das provas, a absolvição seria, de todo modo, a forma mais incólume de procedimento do aparelho judicial, decidida pelo júri popular.

A outra família que considerei estrategicamente posicionada era considerada "braba", sendo o próprio réu um policial a quem boatos imputavam responsabilidade por algumas mortes cometidas nas redondezas. Interpreto hoje como um desafio, uma medição de forças, aquela longa madrugada que este acusado passou bebendo em alguns bares, excepcionalmente abertos para seu uso, ouvindo o som de seu carro ligado no último volume, ligeiramente abaixado a pedido de algum colega policial seu, para logo depois voltar ao nível inicial. Pouco se dormiu nas imediações de sua pequena festa privada e, na manhã seguinte, a noite insone foi assunto em todas as conversas. O julgamento do policial, um dos que mais suscitou expectativas naquela sessão, a bem dizer não aconteceu. Como é usual, os membros do conselho de sentença foram sorteados e admitidos pelas partes, procedeu-se à leitura do libelo acusatório e ao interrogatório do réu. A surpresa aconteceu quando foi dada a palavra ao representante do Ministério Público, para que procedesse à acusação. $\mathrm{O}$ promotor então, em resumido discurso de apenas cerca de 25 minutos Bo tempo de que dispõe, e de que fez uso em todos os outros seis julgamentos, é de duas horasB, pediu a absolvição do acusado, assegurando a total ausência de provas contra ele nos autos. Diante disto, a defesa apenas insistiu junto ao conselho de sentença que tivesse em consideração apenas aquele crime, de que o réu estaria inocente, sem se deixar influenciar por outras imputações de que por 
ventura ele fosse objeto. A absolvição do policial, ansiosamente aguardada, contentou a um público bastante avantajado, instalado no fórum e nas suas imediações.

A tarefa delegada ao conselho de sentença, em outros casos, porém, é muito mais espinhosa. Mesmo quando se conhece os casos e seus protagonistas, réus e vítimas, e suas respectivas famílias, nem sempre o voto é cabalmente decidido por antecipação. Uma inclinação bem pode ser contrariada com as performances no fórum, ainda que obviamente seja mantida a concorrência de fatores exteriores aos autos e ao momento do julgamento em particular. Nestes casos, o Tribunal do Júri parece ter um papel de arbítrio muito mais complexo, dissolvendo a impressão de mero agente oficial que sanciona uma opinião pública previamente formada e virtualmente consensual. São ocasiões em que mais distintamente, a máquina judiciária e a comunidade, em dupla captura, articulam-se peculiarmente na administração de conflitos sociais. Decerto, os conflitos são elementos constitutivos de qualquer sociedade, que desenvolve tolerância em algum grau com relação a determinadas formas de violência. Isso não significa que seja dada de antemão a condição de assimilação pública de um episódio qualquer de disputa.

A respeito do sentimento de honra, Bourdieu (1988: 174) sugeriu sua comparação a uma gramática geradora, que "permite a cada agente engendrar, a partir de número reduzido de princípios, todas as formas de conduta (...) graças a invenções que não seriam de maneira nenhuma exigidas pelo desenvolvimento estereotipado de um ritual". Os comportamentos não são completamente previsíveis, portanto. E tampouco serão previsíveis as avaliações públicas de tais comportamentos, embora sejam sempre fundamentadas em um conjunto limitado de princípios. Certamente, aquilo que se passa no Tribunal do Júri, quando se deve expressar a opinião acerca de um delito, pode ser teoricamente aproximado do que acontece no 'tribunal da opinião', que se pronuncia em relação à honra, mesmo porque o objeto ao qual se referem são coincidentes em alguma medida. ${ }^{14}$ Quero chamar atenção, no entanto, para o fato de um julgamento pelo Tribunal do Júri constituir uma instância em que se pode discutir efetivamente acerca de disputas. E, nesta discussão, tomam parte significativa os membros da defesa e da acusação. Suas performances no tribunal se adicionam às das partes envolvidas nas disputas. É este um dos sentidos em que a máquina judiciária pode se articular à comunidade na gerência dos conflitos.

\footnotetext{
${ }^{14}$ Cardoso de Oliveira (1999), a propósito de um objeto à primeira vista tão distinto quanto as disputas nos tribunais de pequenas causas, sugere que aí também estão em jogo valores morais, não obstante sejam, em regra, dispostos à margem das negociações. Esta disposição seria, inclusive, em sua opinião, responsável pelas limitações que encontrou nas resoluções destes conflitos.
} 
Dentre os julgamentos que acompanhei naquela sessão do júri, considerei o primeiro deles especialmente dramático. Foram vários os fatores que contribuíram para seu elevado grau de dramaticidade $\mathbf{B}$ para além da minha condição de estreante. Tratava-se de um jovem de classe média que aos 19 anos matara outro rapaz de suas relações. A autoria do homicídio havia sido apurada pelo Inquérito Policial, apoiado em testemunhos de um irmão, ainda mais novo, do acusado e de um primo de ambos. Fora da sala do júri corriam os boatos, segundo os quais os conflitos familiares do réu não paravam por aí, pois o próprio pai teria interesse na condenação de seu filho, por ter sido já ameaçado por ele. Durante o julgamento, o promotor fez alusão a algumas atitudes de outros familiares do réu, que indicariam o reconhecimento dele como culpado. Não corroborava, mas, mesmo assim, não deixava de evocar os boatos que circulavam pelas ruas da cidade.

Apesar de toda ambigüidade relacionada ao réu, tanto em relação a seu comportamento naquele crime, quanto à sua situação no seio de sua família, o plenário do júri ficou repleto e, na medida que a hora da votação foi se aproximando, mais pessoas se acercavam do fórum. Várias delas tinham relação de parentesco com o réu, conforme pude apurar, e muitas outras eram curiosas ou amigas. A família dele, em particular através de sua avó Bde quem ele é o neto favorito, embora a maltrate, segundo rezam os comentários na cidadeB, é muito "considerada" em Monte Verde, de modo que aquelas circunstâncias eram bastante perturbadoras. A estas condições já tão peculiares, somou-se a contratação, efetuada pela família, de um advogado do Recife, apesar do parentesco próximo do réu, conhecido de todos, com um dos mais conhecidos profissionais residentes e atuantes na comarca. Esta participação forasteira, decidida a partir de critérios estratégicos, resultou um tanto desastrosa, segundo pude avaliar.

A tese da defesa, ousada, era a de negação de autoria. A tarefa do advogado poderia ser descrita, então, como convencer o conselho de sentença do contrário da certeza de que se alimentava. Tendo ciência disto, o advogado insistia em provar, com pequenas parábolas, que as aparências enganam. Como a do camponês que antecipava, com certeza, uma chuva que, no entanto, não vinha. Tratou, também, de alegar a tortura psicológica a que foram submetidos seu irmão e primo, durante o Inquérito Policial, ${ }^{15}$ e de buscar álibis para seu cliente, baseado nos horários estratégicos que sustentassem sua presença em outro lugar. Para isso, mencionou uma conversa pessoal sua, não constante nos autos, com a conhecida avó do réu, sobre a presença de seu neto, em sua casa, naquela madrugada.

Por seu lado, a tarefa assignada aos jurados parece ter sido decidir sobre um episódio causador de profundo mal estar na comunidade. Não somente pelo assas- 
sinato em si, mas por envolver o jovem de uma família tão bem "considerada". Além disso, as condições de absolvição do réu, naquele julgamento, podem ter sido dificultadas pela forma como foi organizada a defesa. Entre os monteverdenses reinava não um palpite com relação à autoria daquele assassinato, mas uma certeza, corroborada, inclusive, pelo testemunho pessoal, no caso de, no mínimo, um dos membros do conselho de sentença. Esta pessoa comentou, para mim, sobre detalhes relativos aos álibis alegados pelo réu em seu interrogatório, publicamente prestado, no dia do julgamento, que entravam em franca contradição com o que ela havia testemunhado. Outro membro do corpo de jurados confidenciou-me, mais tarde, que não restou, ao conselho de sentença, meio de decidir de outro modo sobre uma discussão girando tão insistentemente em torno da autoria do crime. Segundo suas considerações, se a defesa se concentrasse no pedido de mais uma chance ao réu, possivelmente teria mais sucesso. É claro que os raciocínios explicativos dos resultados conhecidos ganham a aparência de uma lógica irrepreensível, porque asseverados pelos fatos, mas o próprio resultado de $4 \times 3$ evidencia a prevalência de fatores menos lineares. A certeza da autoria nem sempre, como já se viu, é fator suficiente para a condenação e dificilmente é admissível isolar uma causa única para decisões tão críticas. De algum modo, diante do juiz e dos jurados, em supersaturação de elementos, perspectivas e interesses, uma situação social é encenada e discutida, manifestando-se aí a relação de forças em que está introduzida; há muito mais do que justiça em jogo. E sobre esta situação alguns indivíduos são obrigados a decidir. A condenação por homicídio qualificado, resultando em uma pena de 15 anos de prisão para o réu gerou uma forte e silenciosa comoção no plenário, muito agravada, naquela mesma madrugada, pela morte de uma tia do jovem condenado. No dia seguinte, o assunto no funeral fora a visita tardia do jovem algemado à sua avó, para consolá-la do grande dissabor que lhe trouxeram os acontecimentos daquele dia, e a profunda revolta da família com a condenação do rapaz. Na voz de uma tia por afinidade do rapaz, não somente ele, mas toda a família foi atingida pela condenação feita por uma sociedade injusta que, tinha certeza, absolveria os réus subseqüentes daquela sessão, cujos crimes eram muito piores de que os de seu sobrinho. Suas amigas, solidárias, confirma-

\footnotetext{
${ }^{15}$ Segundo Kant de Lima (1989;1986), nos procedimentos policiais, no inquérito policial, e judiciais, na fase de instrução penal, operam princípios distintos (inquisitoriais e acusatórios, respectivamente). Sobre esta distinção estaria apoiado o antagonismo entre as instituições, que assume um forte caráter de desqualificação da polícia pelo sistema judiciário. Mas é também através deste antagonismo que, paradoxalmente, se perpetua a relação nos seus termos tradicionais, garantindo, Inclusive, a penetração "não oficial" no sistema judicial de 'práticas inquisitoriais' que ele mesmo condena. Durante toda a sessão do júri de Monte Verde, a discussão, levantada pela defesa e acusação, do valor da peça do inquérito policial, veio várias vezes à tona, assumindo importância crítica naquele primeiro julgamento.
} 
vam sua certeza, antecipando-me aquilo que sabiam que eu iria testemunhar. A revolta parecia equiparar a condenação do rapaz a um insulto público, uma humilhação pela qual passava sua família.

De certa forma, naquele velório, ocorrido justamente na casa da matriarca da família, voltou a encenar-se o drama agudamente vivido no fórum, em toda a ambigüidade que lhe foi peculiar. Porque não estiveram ausentes do ambiente carregado de pesar, expressões de abjeção pelo crime discutido na véspera, além de parte significativa do elenco de intervenientes nos vários momentos constituintes do processo: além da avó, o pai, segunda esposa deste e irmão do condenado. Próximo a este último, o pivô da acusação no Inquérito Policial, e a poucos metros do pequeno grupo que tentava consolar aquela sua tia, testemunhei uma mulher manifestar para outra, e para mim mesma, um temor hiperbólico com relação à violência como aquela cometida pelo condenado, que a terão afastado de suas habituais caminhada durante a madrugada. Reproduzia, assim, em um cenário particularmente marcado pela tensão de forças diversas, e adversas, uma disposição condenatória que testemunhei várias outras vezes, com relação àquele crime $\mathrm{e}$ mesmo à conduta mais genérica do rapaz recentemente julgado.

\section{Relações em ajuste}

Neste sentido, o Tribunal do Júri parece trazer à tona, explicitamente, um conflito social mais amplo do que aquele que envolve as partes em litígio, embora ele não se traduza cabalmente nos termos em que são proferidos por advogados e promotores, durante os julgamentos. Da mesma forma, o significado da penalidade infligida pelo juiz, mas determinada pela decisão dos jurados, transborda o limite da absolvição ou dos anos cumpridos na prisão. Mesmo não cabendo a si a definição da pena, o júri mostra ponderar bastante em torno dela antes de dar seu voto à defesa ou acusação. Uma mulher alegou, como razões de ter votado a favor da absolvição da ré, o fato desta ter voltado a se casar, com estabilidade, e de não haver em Monte Verde prisão para mulheres: como ela haveria de desempenhar seu papel de mãe de família? A preocupação com a conseqüência de uma condenação pode, então, ter sido tão ou mais relevante do que as considerações acerca da real intenção da acusada ao segurar o marido, se pretendia evitar o pior ou facilitar o trabalho do amante. Raciocínio comparável ao desta jurada foi decerto efetuado por aqueles que condenaram um réu por homicídio simples, resultando em uma sentença de sete anos em regime aberto. Pelas ruas da cidade, o "povo" dizia ter-se tratado de um assassinato "por engano": o autor pensara, equivocadamente, que a vítima havia esfaqueado seu irmão. No julgamento, sua defesa acrescentou ainda 
uma versão para sustentar a tese de legítima defesa que, se acabou por não prevalecer, deve ter auxiliado a evitar a 'qualificação' do crime. Assim mesmo, a viabilidade de dar continuidade à sua vida de provedor da família foi suficientemente discutida durante o julgamento e, tendo sido garantida pela pena branda, não deixou de contentar parentes próximos seus. Em outro caso, a resolução da absolvição pareceu basear-se na piedade dos jurados em relação a um réu com deficiência mental, de origem muito pobre e que teria cumprido, em grande parte por negligência do sistema judiciário, quatro anos em um presídio da capital por ter cometido um assassinato por motivos não compreendidos.

O júri popular realiza, portanto, uma espécie de síntese da relação especial entre representantes da Justiça e da comunidade, que, se pode efetivamente ser descrita como antagônica, não é necessariamente contraditória. Apesar de ditar as coordenadas a partir das quais serão encenados e julgados alguns dramas vividos socialmente, o aparelho jurídico não anula a atuação de forças que lhe são bastante estranhas, percepções nativas de justiça e da forma como devem ser negociados os conflitos. Decerto, a contaminação de perspectivas é dupla e não convém menosprezar os efeitos agudos dos tratamentos jurídicos, dos julgamentos em particular, sobre os arranjos sociais. A mobilização da comunidade em torno dos julgamentos e a delicada situação vivida pelos membros do corpo de jurados dão o testemunho deste impacto. Naquele ritual, vidas estão sendo decididas, posições rearranjadas e focalizadas; e não somente as dos réus, como também daqueles que lhes são mais próximos, ou que cercavam a vítima. Está-se definindo, dinamicamente, neste processo, em suma, um campo de forças, a partir do qual serão estabelecidos os limites e privilégios de cada um e dos atos que lhes são admissíveis. As circunstâncias do julgamento constituem um plano de conjugação de elementos heterogêneos. Fornecem uma ocasião particularmente intensa para as redefinições constantes de princípios ou valores sociais, como a violência e a justiça, das disposições dos termos e das suas relações. Parecem- me, portanto, focos privilegiados para a apreensão da vida social em movimento, para além das regras aparentemente sedimentadas, a que tantas vezes se alude em tais circunstâncias.

\section{Bibliografia}

Bourdieu, Pierre (1988). O sentimento da honra na sociedade cabília. In: Honra e vergonha: valores da sociedade cabilia. Lisboa: Fundação Calouste Gulbenkian, p. 157-195.

Cardoso de Oliveira, Luís R. (1999). Legalidade e eticidade nas pequenas causas. Série Antropologia. Departamento de Antropologia, Universidade de Brasília. 
Código Penal

Código de Processo Penal

Eckhoff, Torstein (1973). The mediator and the judge. In: Vilhelm Aubert (org.), Sociology of Law. Middlesex: Penguin Books, p. 171-181.

Geertz, Clifford (1983). Local knowledge: fact and law in comparative perspective. In: Local knowledge. further essays in interpretative Anthropology. New York: Basic Books, p. 167-234.

Herzfeld, Michael (1985). The poetics of manhood. In: The poetics of manhood. contest and identity in a Cretan Mountain village. Princeton: Princeton University Press, p. 3-50.

Kant de Lima. Roberto (1989). Cultura política e práticas policiais: a tradição inquisitorial. Revista Brasileira de Ciências Sociais, 10(4): 65-84.

BBBBB (1986). A administração de conflitos no Brasil. In: Gilberto Velho e Marcos Alvito (orgs.). Cidadania e violência. Rio de Janeiro: Editora UFRJ: Editora FGV. p. 165-177.

Pitt-Rivers. Julian (1977). The fate of shechem or the politics of sex: essays in the Anthropology of the Mediterranean. Cambridge: Cambridge University Press. 